Summon up every page and every line, Every labor and love of Hercules,

Every last reading of every manuscript.

In the first century of the Hégira,

I, that Omar who subdued the Persians

And imposed Islam over all the earth,

Order my soldiers to destroy with fire

The endless Library and all its works,

Which shall not perish. Blessed be the Lord

Who does not sleep, and His Apostle, Mohammed.

translated by Robert Mezey

\title{
General Quiroga Rides to His Death in a Carriage
}

The bare arroyo now without even a thirst for water

And a moon fading away in the icy sky of dawn

And the countryside dead of hunger, poor as a spider.

The carriage swayed groaning and creaking up the hillside:

A monstrous diligence, funereal and emphatic.

Four coal-black horses, their blackness the emblem of death,

Tugged along six terrors and one unsleeping bravado.

Alongside the postillions a Negro was riding.

To ride to one's death in a carriage, how very stately!

General Quiroga desired to enter the shadow

Taking with him an escort of six slit throats or seven.

Foul-mouthed rowdies from Córdoba (Quiroga was musing), How can they hope to withstand the weight of my presence?

I am invested here, I am made fast in this life

Like the end of a picket rope tamped into the pampa. 
I who have lived through so many thousands of evenings, I whose very name sets fields of lances to trembling, Will never relinquish my life in this place of stonesCould the wind off the Andes die, perhaps? or sabres?

But when the day glittered over Barranca Yaco, There rained down heavy upon him the merciless steel;

Death, which is common to all, made off with this Riojano And one of the thrusts whispered something about Juan Manuel.

Now dead, now standing again, now immortal and a ghost, He reported to the hell God had appointed for him, And under his orders went the bloodless and tattered host, Armies of souls in torment, souls of men and of horses.

\section{translated by Richard Barnes and Robert Mezey}

\section{Clouds}

There is nothing that is not essentially a cloud. Cathedrals reared of massive stone and biblical stained glass time will throw down are clouds. And so too is the Odyssey, which changes like the ocean: something different each time we open it. Your aging face is now a different face in the looking glass, and each day is a nebulous labyrinth. We are the ones who drift away. The host of evening clouds dispersing in the west is our very image. Without pause or rest the rose changes into another rose. And you are cloud, ocean, oblivion's mist. And you are also all that you have lost. 